\section{環境にやさしい新エネル ギー供給システム}

○一 新エネルギ一供給システム, 地産地省, マイクログリッド

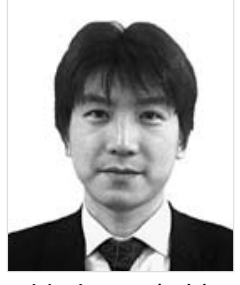

井上 真壮

\section{1.はじめに}

2005 年 2 月に京都議定書が発効し，我が国には 2008 2012 年の 5 年間の平均で 1990 年比 $6 \%$ の温室効果ガス 削減が求められている。しかしながら，省エネルギーへの 取組み以上にエネルギー需要の増加が大きく, 温室効果ガ スは逆に 2004 年度の段階で $7.4 \%$ も増加した。省エネル ギーによる削減対策に限界が見えてきた中で，新エネルギ 一は有効な温暖化対策の一つである。また，新エネルギー の普及拡大に伴い，これまでになかった新しいビジネスが 生まれるという新産業創出の可能性も期待されている。

一方，新エネルギーの普及には多くの課題も残されてい る。最大の課題は，技術的な課題ではなく経済性である。 新エネルギーにはこれまで政策的に技術開発への投資が行 われており，飛躍的な技術の進歩を遂げてきた。しかしな がら, 発電技術は進歩しているものの, 従来型の発電機や 電力会社と比較すると経済性で劣る。いくら環境に優れた システムでも経済性で優れていなければ，結局のところ人 の善意に依存したものでしかなく, 本当の意味での普及拡 大は望めない。

新エネルギーの普及に向けては政策的に高い目標が定め られているものの，我が国の消費エネルギー全体から見れ ばほんのわずかな量にすぎない。当然のことながら，量が 少ないので，量産効果によるコストダウンに過度な期待は できない。発電コストの削減に限界があるため, いかに経 済性に見合った供給システムを組み上げるかの発想が重要 ということだ。

本稿では，上記のような考え方に基づき，新エネルギー について主としてビジネスとしての可能性の観点から概観 したい。

いのうえ・まこと 1998 年早稲田大学大学院理工学研究科 修了 (工学修士)。同年, 日本総合研究所入社。現在創発戦略 センター主任研究員，エネルギービジネスクラスター所属。

\section{2. 新エネルギーを取り巻く環境}

新エネルギーは一次エネルギーのうちの約 1.3\%（2002 年度）を占めており，政府は 2010 年度にこの割合を $3 \%$ にすることを目標としている。新エネルギーの中でも特に 発電分野に位置づけられている太陽光発電, 風力発電, バ イオマス発電はそれぞれ高い目標が設定されている。

\section{1 技術動向}

\section{（1）太陽光発電}

太陽光発電の導入量は, 2003 年度末で 113.4 万 $\mathrm{kW}$ で あり，2010 年度の導入目標が 482 万 $\mathrm{kW}$ とされている。 我が国の太陽光発電の導入量は世界一であり，全世界の約 50\%のシェアを占める。これは，政策的な支援に基づい た導入量の増加で大幅なコスト削減が進んできたためだ。 しかしながら，政府の補助も 2006 年度で終了する見込み となっている。

一方，現時点の発電コストは 50 円 $/ \mathrm{kWh}$ とまだまだ高 い水準である。初期投資を回収するには，最も電力単価の 高い家庭 $(20$ 円 $/ \mathrm{kWh})$ でも 20 30 年かかると言われ る。今後は，家庭用に加えて事業用への展開が期待されて いるが，売電単価の観点から発電事業として成立するため には更なるコスト削減が不可欠である。現在，結晶シリコ ン系よりも低価格な素材である化学半導体系の太陽光発電 が研究されているが，この成果により大幅なコストダウン が期待されている。

(2) 風力発電

風力発電の導入量は, 2004 年度末で 95.6 万 $\mathrm{kW}$ であ り，2010 年度の導入目標が 300 万 $\mathrm{kW}$ とされている。風 力発電は 1990 年ごろに導入が始まり, 当初は電力会社や 自治体が研究用やデモンストレーション用に設置してき た。1998 年に電力会社による風力発電の電力買取制度が できたことで事業用の風力発電が急速に普及した。また, そのシンボル性と管理が比較的容易であることから，市民 や NPO 主導による導入も進んでいる。近年では発電設備 の大規模化も進んでいる。当初 $250 \mathrm{~kW}$ 程度であった発電 
出力は今では $2,000 \mathrm{~kW}$ 級にまで拡大した。

一方, 風力発電は, 風況に優れた北海道, 東北, 九州に 偏在している。そのため, 一部地域では, これ以上の風力 発電の普及が電力系統の周波数などに悪影響を及ぼすこと が懸念されており導入が制限され始めている。蓄電池など を併設することで風力発電の出力を安定化させることも検 討されているが, 追加の設備負担は事業性の低下につなが るため, 導入スピードの低下が懸念される。

(3) 廃充物発電十バイオマス発電

廃棄物発電およびバイオマス発電の導入量は, 2002 年 度末で 161 万 $\mathrm{kW}$ であり, 2010 年度の導入目標が 450 万 $\mathrm{kW}$ とされている。バイオマスには, 木質系, 農業・畜 産・水産系, 食品産業系など多様な種類が存在している。 現在利用されているバイオマスエネルギーは廃棄物の焼却 によるものがほとんどであり, 先ほどの目標もその大部分 を廃棄物発電で達成することが想定されている。廃棄物処 理施設については, 特に一般廃棄物を中心に 1990 年代後 半からダイオキシン対策のための集約・大規模化が進めら れ，同時に発電によるサーマルリサイクルが推奨されてき た。発電効率が $10 \%$ 程度と低いことが課題となっていた が, 最近ではスーパーごみ発電や RDF 発電など発電効率 が高い設備の導入も始まっている。

また, 廃棄物発電以外にも, 木質バイオマスの発電施設 が増えている。これは, 発電単価が比較的安価であり, 後 述するRPS 証書価值も付くので発電事業として成立する ようになったためである。そして, 出力も太陽光発電や風 力発電のように自然環境に影響を大きく受ける発電機と比 べ安定して利用が可能であることも優れた特徽である。

一方，湿潤系バイオマスからバイオガス $\left(\mathrm{CH}_{4}\right.$ が $60 \%$ 程度の燃料ガス) を取り出し, 発電燃料として活用するも のについては, ガス化技術は確立されているものの, 収 集・輸送に多額の費用がかかるという課題から, 下水処理 場などの一部の公共施設を中心に導入が始まったに過ぎ ず, 家畜排泄物や食品廃棄物での利用は進んでいない。

\subsection{RPS 制度の誕生}

RPS（Renewable Portfolio Standard）制度とは，「電気 事業者による新エネルギー等の利用に関する特別措置法」 に基づき, 電気事業者に対して, 販売電力量に応じた一定 割合以上の「新エネルギー等電気」の利用を義務付けるも のである。2003 年 4 月より施行された。「新エネルギー等 電気」とは, 風力, 太陽光, 地熱, 水力 (水路式の $1,000 \mathrm{~kW}$ 以下の水力発電), バイオマスによる電力であ る。電気事業者は, 義務を履行するため, 「新エネルギー 等電気」を自ら発電する, ほかから「新エネルギー等電 気」を購入する,「新エネルギー等電気相当量 (RPS 証
書)」を取得することができる。

RPS 制度の成立以前は, 化石燃料による発電機と比較 して発電単価の高い新エネルギーは地元電力会社の自主的 な支援に依存して普及してきた。これは, 太陽光, 風力, 一般廃棄物発電といった新エネルギーの種類によって, 電 力を通常の価格よりも優遇した固定価格で買取るというも のである。RPS 制度により，化石燃料による発電機と新 エネルギーの発電単価の格差が埋められた。これにより, 完全な市場取引だけで新エネルギー発電事業が成立する可 能性が出てきたのである。

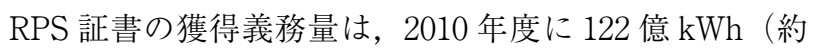
1.35\%）である。2004 年度は, 義務量 36 億 $\mathrm{kWh}$ に対し, 供給総量は 49.1 億 $\mathrm{kWh}^{(1)}$ であった。2009 年まで経過措置 で利用目標量に対して義務量は低めに設定されているもの の, 2010 年度の水準には供給量を約 2.5 倍に拡大する必 要があり, 一部の電気事業者では 2010 年度の達成が危ぶ まれている。また, 2010 年度以降の義務量については来 年度に決定される計画である。

一方, RPS 証書の価格は, 上限価格 11 円 $/ \mathrm{kWh}$ 以下 で, 市場で決定される。2004 年度の価格水準 ${ }^{(1)}$ は, 平均 4.8 円 $/ \mathrm{kWh}$ （最低 4.0 円 $/ \mathrm{kWh} \sim$ 最高 8.0 円 $/ \mathrm{kWh）であ}$ った。RPS 証書の価格は, 電気事業者に課される獲得義 務量の大小によって大きく左右される。また, 新エネルギ 一事業者にとって RPS 証書は主要な収入源の一つとなる ことから，RPS 証書の義務量の動向が注目されている。

\section{3 電力自由化の進展}

1999 年 5 月に電気事業法が改正され，2000 年 3 月から 小売の部分自由化 $(2,000 \mathrm{~kW}$ 以上の特別高圧) が始まっ た。以降, 段階的に自由化範囲は拡大し, 2005 年 4 月に は高圧 $50 \mathrm{~kW}$ の需要家までが対象となった。これは, 全 小売電力量の $60 \%$ 以上を占める市場である。また, 2007 年以降に $50 \mathrm{~kW}$ 未満の需要家までを含めた全面自由化の 検討を行うこととされている。

すでに, 自由化に伴い, 新規事業者である特定規模電気 事業者（PPS； Power Producer \& Supplier）が 23 社誕生 した ${ }^{(2)}$ 。PPS の誕生は, 新エネルギーにとって新たな可能 性を生み出している。PPS は電力を発電もしくは外部か ら調達し需要家への小売を行うが, 条件が合えば新エネル ギー発電設備も PPS の調達電源となるためである。すな わち, 新エネルギー発電事業者にとって, 電力会社以外に も販売先の選択肢が拡大することになる。

すでに, PPS と電力会社が競争することで売電単価が 上がっている例は見られる。自治体の一般廃棄物発電に は, 電力の販売先を PPS に切り替えることで売電収入を 増やしている例がある。電力自由化により, 新エネルギー 
の発電電力は単一価格でなくなったのである。

\section{3. 新エネルギーの普及に向けたポイント}

\section{1 自立したビジネスモデル}

新エネルギー普及に向けた第一のポイントは, 電力系統 に悪影響を与えないような仕組みを構築することである。 実際, 風力発電については, 一部地域において, 電力系統 への悪影響を回避するために，設置希望に対して電力会社 による購入枠が少なく, 入札や抽選に当たらないため事業 ができないという現象が起きている。これは，風力発電が 増えたことによる系統の品質問題がもとにあるが, 電力自 由化による価格競争が進む中で, 電力会社がいつまで新エ ネルギーを優遇価格で購入してくれるかも不透明だ。新エ ネルギーがさらに普及するためには，こうした購入枠や優 遇された買取制度に依存せずに事業が成立しなくてはなら ない。

具体的には，新エネルギー電力を電力会社だけでなく PPS にも販売できることが必要である。そのためには, 計画的な発電ができなくてはならない。現在, 新エネルギ 一のうち売電事業として進んでいるのはバイオマス発電と 風力発電である。しかしながら，風力発電は自然環境の影 響が大きく, 出力の変動が大きいことから電力会社以外へ の販売はできていない。PPS や卸電力取引所などほかの 選択肢を選択できるレベルに電力品質を上げることが，更 なる普及に向けて必要と言える。

電力品質の目標になるのは, PPSの需給バランスの基 準である 30 分同時同量（30 分で発電量と需要量を $\pm 3 \%$ 以内に制御）である。PPS は顧客の需要量と発電量を 30 分同時同量で収めることを目標に電源の制御を行ってい る。実際には，調整電源を所有するなどして直前の需要の 変化などに対応していることから, 当面は新エネルギー電 源にそこまでの制御レベルを求めないだろう。しかしなが ら，新エネルギー電源の量が増えてくれば，必ずより厳し いレベルの制御を求められる。最終的には, それは 30 分 同時同量となる。例えば，風力発電は故障などにより突然 運転を停止することがあるが, 数十万 $\mathrm{kW}$ のうちの数千 $\mathrm{kW}$ 程度の新エネルギーであれば直前で対応できても, 数 万 $\mathrm{kW}$ になると直前での発電量変更への対応が困難とな る。

計画発電による事業性向上のイメージは図 1 のとおりで ある。発電量が計画できる分，電力を高值で販売すること ができるため, 出力安定化のための追加投資を伴っても事 業性が確保できる可能性がある。また，メリットとして電 力会社の購入枠によらず発電所の建設が実施できることも 挙げられる。

\section{2 地産地消の実現}

地産地消とは，「地域で産まれたエネルギーを地域内で 消費する」ということである。地産地消は，近年の新エネ ルギー導入拡大に向けて掲げられてきたコンセプトである が，実際のところは，新エネルギーは「地産」であったが 「地消」ではなかった。例えば，風力発電が建てられても 発電された電力は送電線を通じて火力や原子力の電力と混 合され，不特定多数の需要家に届けられるため，地域で新 エネルギーを使っているわけではない。新エネルギーを普 及するための第二のポイントは，本当の意味での「地消」 の実現，すなわち地域での使い方の工夫である。

新エネルギーの発電電力は化石燃料による発電電力より 出力が不安定であるため，これを安定させるための仕組み がなくてはならない。ただし，供給側にすべて任せてしま うと経済的に成り立たない。そこで求められるのが，需要 側での工夫や協力である。

これには，大きく分けて二つの方向性が考えられる。一 つは，供給先となる需要選定を新エネルギーに有利に行う ことだ。例えば，低品質電力で許容できる負荷への供給も あるだろう。季節限定であるが，ロードヒーティングであ れば品質を整えるためにコストをかける必要はない。ま た, 逆に, 品質はしっかり整えて, 電力単価の高い需要家 に使ってもらうことも考えられる。電力単価は需要規模や 負荷率によって異なるが，少しでも供給条件の有利な需要 家に利用してもらうことが新エネルギー側にとって事業性 確保の近道となる。

もう一つの方向性は, 需要家にできるだけ新エネルギー の発電量に応じた電力利用をしてもらうことである。新エ ネルギー発電の出力に応じて完全に需要をコントロールし てもらうことはできないが，需要家で分散型電源を所有し ていれば，その出力制御を新エネルギーの出力に応じて行

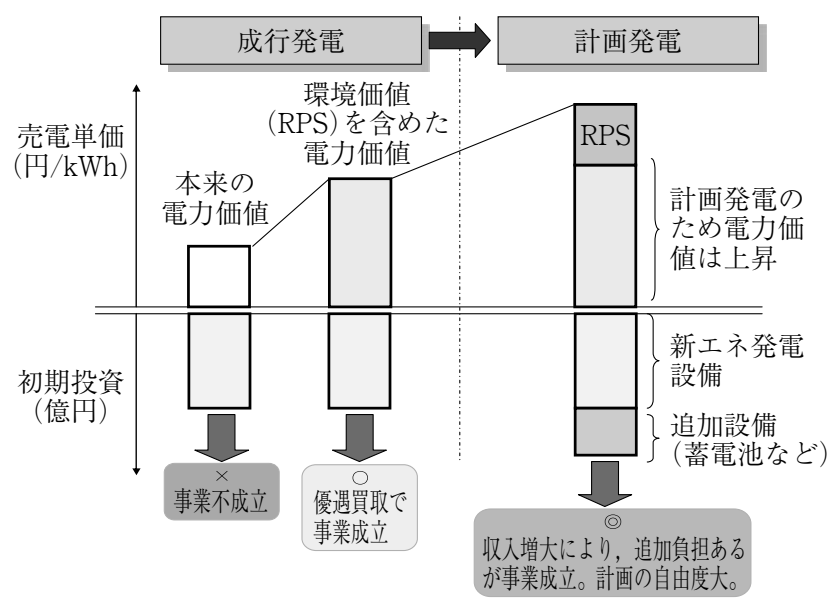

図 1 計画発電による事業性向上 
ってもらうことは可能だろう。こうした地産地消を実現す るためには，そもそも需要家の新エネルギーに対する理解 が必要である。新エネルギーと需要家の関倸がかなり密接 になることを前提としたシステムだからだ。「地産地消」 の「地消」を実現することとは新エネルギーに関する需要 家の自覚を高めることと同義と言える。

\section{4. 新エネルギー供給システムの方向性}

以上のポイントを踏まえた新エネルギー供給システムと しては, 大きく 2 種類の方向性がある。一つは, 計画発電 型の IPP で，もう一つはマイクログリッドである。

\subsection{IPP (計画発電型)}

計画発電型の IPP とは, 30 分単位での発電量を事前に 約束して発電を行うものである。発電量が事前に分かれ ば，販売先を電力会社だけではなく, PPS や卸電力取引 所に拡大できるし, 発電電力をより高い価格で販売するこ とができる。しかしながら, 出力が自然環境に影響される 新エネルギーだけでは実現は困難である。そこで, 蓄電池 や分散型電源などの併設が必要となる。

木質バイオマス発電は, 質 (熱量) と量（焼却量）によ って発電量が変動するが，質の変動はわずかなので量を調 整すれば発電を計画的に行うことは比較的容易である。一 方, 問題となるのは風力発電や太陽光発電のように自然環 境に大きく影響を受ける電源だ。

なんの工夫もなければ，蓄電池や分散型電源を併設して 風力発電や太陽光発電に上る発電量を事前に約束するに は, 少なくとも同規模以上の蓄電池や分散型電源が必要と なる。しかし，蓄電池や分散型電源は高価なので，あまり 大きな蓄電池や分散型電源を設置すると事業が成立しな い。そこで, 期待されているのが気象予測を活用した発電 量の予測システムである。気象情報を活用することで， あ らかじめ発電量を予測するので, 最小の蓄電池や分散型電 源で発電量が調整できる。もちろん誤差はあるが, 予浿誤 差分の蓄電池や分散型電源を見込んでも，何もしない場合 と比べて設備の効率化が図れる。まだ，実例は存在してい ないが，近い将来に期待されるビジネスモデルである。

\section{2 マイクログリッド}

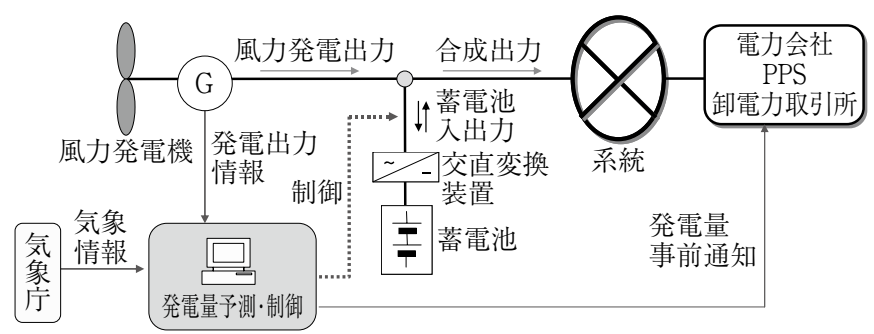

図 2 計画発電型 IPP（風力発電）
マイクログリッドは地産地消のシステムで，限られた地 域の中で複数の電源と需要をネットワークした独立性の高 いエネルギーシステムである。八戸市のマイクログリッド では, ネットワーク単位で電力の需給バランスや品質を維 持することに加え, すべての電力需要を新エネルギーで賄 っている。マイクログリッドは，このように新エネルギー の利用割合を最大化できる究極の新エネルギー供給システ ムと言える。

しかしながら，マイクログリッドを商用ベースで行うに は, 二つの課題がある。一つは, 新エネルギーのコストに 加え自営線や需給バランスを保つための制御にコストがか かることである。電力の販売という観点から見ると, 直接 需要家に電力供給できるため, 販売単価は小売単価と同等 となり, IPPよりも有利な条件となる。一方, 制御のコス トが高いと事業として成り立たない。現時点では, まだ実 証段階であるが，将来的には汎用の安価な制御システムが 求められる。

もう一つの課題は, 規模である。事業性を向上させるに は, 規模が大きい方が有利だ。例えば, 風力発電では小型 のものよりも $1,000 \mathrm{~kW}$ 級以上を複数並べたウィンドファ 一ムの方が発電単価で優れる。規模を大きくすると，それ に見合った需要が必要となるが, 規模が大きくなった分だ け自営線の設置費用などが増大して事業性を圧迫する。

まとめると, マイクログリッドに適するのは, 競争力の ある新エネルギー発電設備に近接して, 需要家が密集して 存在し，かつ需要規模の大きな地域と言える。これには， 地域の工業団地などが合致するだろう。今後は, 工業団地 などの大規模需要を対象とした新エネルギーのマイクログ リッドが期待される。

\section{5.おわりに}

新エネルギーを安定的に普及させるには，事業性と参入 自由度の両立が必要であることを述べた。京都議定書の発 効以降, 新エネルギーに対する期待感はさらに高まり, か つ規制緩和により市場も開けるなど周辺状況は追い風であ る。ここで述べたような新エネルギー供給システムには課 題も残されているが，一部はすでに実証が始まっており実 用化も間近である。追い風を受けて，導入目標を超えて新 エネルギーが継続的に普及拡大することに期待したい。

(平成 18 年 2 月 20 日受付)

（1）資源エネルギー庁：R P S 法下における新エネルギー等電気等 に係る取引価格調査結果

（2）資源エネルギー庁ホームページ：http：//www.enecho.meti. go.jp/ 